\title{
THE DILEMMA OF CHOOSING THE FORM OF VAT TAXATION IN AGRICULTURE IN POLAND
}

Tomasz Kondraszuk ${ }^{1}$, Phd; Jacek Jaworski ${ }^{2}$, Phd

${ }^{1}$ Faculty of Economics, Warsaw University of Life Sciences, Poland;

${ }^{2}$ Department of Finance, WSB University in Gdansk, Poland

\begin{abstract}
The aim of the paper is to present the most important problem of VAT in Polish agriculture. The key issue concerns the assessment of the attempt to optimize the economic and financial performance of the VAT settlement. The farmer chooses and settles VAT in a flat-rate system or according to the general rules. The question is which form is more favourable. On the basis of mathematical formulas, an appropriate criterion has been selected for the choice of the form of VAT settlements in agriculture.

Even though VAT has been functioning in Polish agriculture for many years, its rules are misinterpreted. From the point of view of the ordinary farmer, it means many cases of erroneous choices which, consequently, reduce his efficiency. This paper systemises knowledge in this regard. It also shows possible changes in the law and their potential impact on farmers' choices of a VAT taxation form.
\end{abstract}

Key words: value added tax (VAT), agriculture, a flat-rate VAT farmer, management, finance.

JEL code: H21, Q14, G32

\section{Introduction}

The value added tax (VAT) has been in force in Poland since 1993. It was regulated by the Act of 8 January 1993 on tax on goods and services and on excise duty (Journal of Laws of 1993 No. 11 , item 50). The application of VAT is not only an organizational and financial problem, but also a mental one, in particular for farmers. VAT was associated with taxes, and therefore additional charges. Misunderstanding the essence of VAT caused the subjective exemptions from VAT to be selected. It meant that the farmers purchasing the means of production were treated as final consumers. VAT in agriculture was introduced seven years later. On 20 July 2000, the Parliament, accepting the Senate's amendment to the amendments to the above mentioned Act, decided to introduce a $3 \%$ VAT rate in agriculture. At the same time, two possibilities of its settlement were introduced, a flat-rate form (specific for farmers) and under general rules similar to other taxpayers.

The subject of the VAT in agriculture has been undertaken by many Polish authors. In relation to agriculture, this topic was taken up by Szelagowska, Goraj (2000), Dziemianowicz (2006), Wegrzyn (2007), Filipiak (2007), Gruziel (2009), Turowska (2010), Zabielska (2011), Sadowski and Baer-Nawrocka (2011), Brodzinska (2015), Kondraszuk (2016). Attempts have also been made to build online calculators to calculate the effects of choosing the form of VAT taxation (ksiegowosc.infor.pl, podatki.egospodarka.pl). The publications mentioned also focus on the problem of choosing a form of VAT taxation along with the economic assessment of its effects. The previous analysis of these publications (Kondraszuk, Jaworski 2017) proves that this problem poses great difficulties even for experienced authors and has not been definitively resolved to date.

The aim of the paper is an attempt to answer the question how to determine the criterion of choosing a form of VAT taxation in agriculture in Poland. Mathematical formulas have been used to determine the final criterion, which allowed the authors to derive the objective function determining the threshold point for the farmer to decide whether to stay on a flat-rate form or switch to the general taxation rules. The paper also indicates the perspectives for changes in the VAT taxation in Poland and their possible impact on the farmers' situation. 


\section{The specifics of VAT taxation in Polish agriculture}

Currently, the VAT rules are regulated by the Act of 11 March 2004 on tax on goods and services (UoVAT) in Poland. This Act, like the previous one, provides the farmers with two forms of taxation. The first one is the general rules which apply to all other taxpayers. The tax liability is calculated by the farmer as the surplus VAT due from sales of agricultural products ( 5 or $8 \%$ ) over VAT charged from general purchasing transaction (5, 8 and $23 \%$ ). For this purpose, the farmer is obliged to keep appropriate records and prepare tax statements. The second option is to choose the flat-rate form of taxation. In this case, the farmer is exempt from tax registration and its settlement. It is done by the recipient of agricultural products by issuing the so-called RR invoice with calculated flat tax of $7 \%$. The purchase price together with this tax is transferred to the farmer. After making the payment, the buyer acquires the right to reduce the tax due by the mentioned tax charged. It is worth pointing out that this form of taxation is only granted to farmers who do not keep accounting books.

Two forms of VAT taxation, in the flat-rate form and according to the general rules, gave the farmer the opportunity to choose a more favourable solution. The assessment criterion, which solution is better, includes both economic and financial as well as organizational and mental aspects. For a flat-rate taxpaying farmer, VAT due received from the buyer of agricultural products is a type of income. On the other hand, the farmer bears the VAT tax burden if he purchases means of production (current and fixed assets). It is a type of cost for the farmer. In this situation, the fundamental VAT principle, the economic neutrality, does not apply. Additional income or loss is generated for farmer taxed under flat-rate rules.

Farmers, who resign from the proposed simplification and switch to general rules, can reduce VAT due by VAT charged. In this way, they can fully implement the principle of VAT economic neutrality.

\section{Economic and financial consequences of VAT taxation}

The fundamental VAT principle for a taxpayer is economic neutrality. It means that the VAT burden is borne solely by the final consumer of goods or services as the final link in the economic turnover ${ }^{1}$.

At the level of a single economic entity, a proper understanding of the impact of VAT settlement on its financial situation is very important. The authors mentioned in the introduction as well as managers of informational websites have tried to solve this problem. The analyses conducted by Kondraszuk (2016) and Kondraszuk and Jaworski (2017) have demonstrated that these calculations contain numerous errors, e.g.:

- incorrect categories used to calculate VAT: Filipiak (2007), Brodzinska (2015);

- incorrect criterion for assessing the benefits of shifting to general rules of taxation: Wegrzyn (2007), Filipiak (2007), Gruziel (2009), Zabielska (2011), Brodzinska (2015), eGospodarka.pl, Infor.pl;

- incorrect assessment of economic effects of the flat-rate settlement of VAT: Gruziel (2009), Turowska (2010), Brodzinska (2015), eGospodarka.pl, Infor.pl;

- incorrect calculations in profit and loss statements: Turowska (2010), eGospodarka.pl.

Therefore, the problem of choosing the form of VAT taxation remains open and at the same time very important from the point of view of the farmer who is obliged to make a choice.

${ }^{1}$ This situation concerned the farmers until 2000. They were treated like consumers. 
For a flat-rate taxpaying farmer, the key question is: who is the buyer of his agricultural products? If it is a VAT payer taxed under the general rules then a sale transaction takes place at net prices with maintaining a $7 \%$ flat-rate VAT refund. However, if the buyer is a flat-rate taxpaying farmer as well as a final consumer, then obtaining a net price plus a $7 \%$ flat rate rebate does not necessarily occur. The gross price can be negotiated. When a flat-rate taxpaying farmer wants to get the equivalent of a flat-rate VAT, the price should be similar to prices offered by other suppliers, for example farmers who are taxed under general rules. They will sell their products at net prices plus VAT due ( $5 \%$ or $8 \%$ ). The gross sale price obtained is revenue for a flat-rate taxpaying farmer.

It is also important, from whom farmers will buy current and fixed assets for their farms. They can buy them from flat-rate taxpaying farmers and then they will negotiate the gross price as described previously. They can also buy from farmers taxed under general rules or, what happens most often, from specialized commercial companies also paying VAT under general rules. Then the gross price will include the net price plus VAT ( $5 \%, 8 \%, 23 \%$ ), which will be a cost for the flatrate taxpaying farmer.

In the case of a purchase, there is also a difference in benefits between a flat-rate taxpaying farmer and a VAT payer under general rules. In this case, the second one is in better situation. A farmer taxed on general rules can reduce a tax due by tax charged (5\%, $8 \%, 23 \%)$. The flat-rate taxpaying farmer has to include tax charged to the costs.

\section{Flat-rate or general rules of taxation?}

In an attempt to recognise the economic consequences of VAT settlements, all possible combinations of sales and purchases by flat-rate taxpaying farmers and farmers taxed under general rules should be distinguished. Here (GR) means the farmer taxed under general rules and (FR) means the flat-rate taxpaying farmer. There are four possibilities of transactions between them:
a. (GR) sells to (GR),
b. (GR) sells to (FR),
c. (FR) sells to (FR),
d. (FR) sells to (GR).

These transactions for one entity may occur jointly. Both: the VAT payer taxed under general rules and the flat-rate taxpaying farmer can sell simultaneously to (GR) and (FR). Let the total sales be equal to:

$$
S=S G R+S F R
$$

where:

SGR - means the sale to a VAT payer taxed under general rules,

SFR - means the sale to flat-rate taxpaying farmer.

For cases (a) and (b), net amounts will go to the profit and loss account on the seller's side. However, VAT due on sales (VS) will be settled from the tax office after its reduction by the tax charged. In this way, the principle of VAT economic neutrality will be implemented.

For cases (c) and (d), gross amounts are transferred to the income statement of the seller and these amounts will not be settled with the tax office. At the moment, the profitability of the flatrate form in relation to the general rules of taxation is determined. 
For case (c) the calculation of return from SFR (VSFR) will occur (calculated the VAT rate of $5 \%, 8 \%$ ). For case (d) the VAT amount (VSGR) will be refund from the payer taxed under general rules to flat-rate taxpaying farmer (calculated at the flat rate $-7 \%$ ). When the flat-rate taxpaying farmer carries out both types of sale, the total VAT refund is:

\section{VSF $=$ VSFR + VSGR}

The purchase transactions may also be presented in four variants:

e. (GR) buys from (GR),

f. (GR) buys from (FR),

g. (FR) buys from (FR),

h. (FR) buys from (GR).

Similarly to sales, the purchase transactions for a single farmer may occur together. Both a VAT payer taxed under general rules and the flat-rate taxpaying farmer can buy simultaneously from $(G R)$ and $(F R)$ :

$$
P=P G R+P F R
$$

where:

PGR - means purchase from VAT payer taxed on general rules,

PFR - means purchase from flat-rate farmer.

For cases (e) and ( $f$ ) net amounts will go to the income statement of the buyer of agricultural products. VAT due from sales in the case of (e) will be calculated based on rates of $5 \%$ and $8 \%$, and in the case of ( $f$ ) based on the flat rate of $7 \%$. In both cases, these amounts will be settled with the tax office and the principle of VAT economic neutrality will be implemented.

For cases $(\mathrm{g})$ and $(\mathrm{h})$ gross amounts are transferred to the income statement of the buyer and they will not be settled with the tax office. At this point an additional cost arises for the flat-rate taxpaying farmer. So, for case (g) we will have the same situation as in (c) - (VPFR) calculation refund payable by the buyer to the seller (negotiable at the VAT rate of $-5 \%, 8 \%$ ). For case (h) the situation will be the same as in (b) - (VPGR) VAT charged on purchases from VAT payer taxed under the general rules (at the rate: $5 \%, 8 \%, 23 \%$ ) will not be settled with the tax office.

When the flat-rate taxpaying farmer carries out both types of purchase, total VAT charged included in the costs is equal to:

$$
\text { VPF }=\text { VPFR }+ \text { VPGR }
$$

In order to finally answer the question, what is more profitable for a farmer, a flat-rate form or the general rules of VAT taxation, the economic result should be calculated for both cases and compared.

The economic result (ERGR) of a farmer taxed under general rules is equal to:

$$
\text { ERGR }=\mathbf{S}-\mathbf{P}=(\text { SGR }+ \text { SFR })-(\text { PGR }+ \text { PFR })
$$

Whereas for the flat-rate taxpaying farmer:

$$
\mathrm{EFFR}=\mathrm{S}-\mathrm{P}=(\mathrm{SGR}+\mathrm{VSF})-(\mathrm{PGR}+\mathrm{VPF})=(\mathrm{SGR}+\mathrm{SFR}+\mathrm{VSGR}+\mathrm{VSFR})-(\mathrm{PGR}+\mathrm{PFR}+\mathrm{VPGR}+\mathrm{VPFR})
$$

In order to assess whether the switching from flat-rate form to the general rules of taxation is beneficial (BoV), the difference between the economic results of VAT payer taxed under the general rules and the flat-rate taxpaying farmer must be calculated:

$$
\text { BoV }=\text { ERGR }- \text { ERFR }=(\text { SGR }+ \text { SFR })-(\text { PGR }+ \text { PFR })-
$$


$[(S G R+S F R+V S G R+V S F R)-(P G R+P F R+V P G R+V P F R)]=V P G R+V P F R-V S G R-V S F R$

and finally:

$$
\mathrm{BoV}=\mathrm{VPF}-\mathrm{VSF}
$$

As a result, a very simple criterion is created allowing farmers to assess the benefits of switching from the flat-rate form to general rules of VAT taxation. If BoV is positive, then it is worth considering the choice of the general rules of taxation. However, it should be remembered that the general rules also include more obligations related to registration which causes transaction costs (TC). Therefore, if a farmer considers giving up flat-rate form of taxation and switching to general rules, then the criterion of profitability of this decision takes the form of the following formula:

$$
\mathrm{BoV}=\mathrm{VPF}-\mathrm{VSF}-\mathrm{T}>0
$$

It means that a flat-rate taxpaying farmer should continue operating on a flat-rate form of taxation even if it results in a loss but this loss does not exceed the transaction costs related to VAT settlement under the general rules.

\section{Prospects for changes in the VAT taxation in Polish agriculture}

Recently, a significant problem in the discussion on the functioning of VAT in Poland has been the tax gap growing at a significant rate. This tax gap results from the difference between VAT, which according to the calculations based on the structure and size of GDP, should go to the budget and the amount actually charged. It has more than doubled in Poland in the past few years (Tratkiewicz 2016). In the light of such a dynamically growing gap, the solutions limiting it are sought.

The first solution, already implemented in Poland is the Unified Control File. VAT payers under general rules of taxation are obliged to send this file to the tax administration electronically. It contains a list of purchase and sale invoices for a particular period and enables the tax administration to quickly verify the transactions conducted on the market. This obligation from 2018 also applies to farmers taxed under VAT general rules.

Another solution (currently piloted) which is implemented in Poland is the split payment. It is based on separating every payment between VAT payers into two parts: the net amount and VAT tax. Each of them should be regulated, but also accepted on separate bank accounts. Funds accumulated on the account intended for VAT cannot be used for any other purpose (Pastuszka 2016). It is envisaged that in the next two years this obligation will also apply to farmers taxed under VAT general rules.

On the other hand, the European Commission has announced a proposal to amend the VAT rules, inter alia, by increasing the freedom for Member States to set the rates of this tax. The list defining what may be covered by reduced tax rates will also disappear. Therefore, changes in the tax rates of VAT for farmers should also be expected. It will probably concern both flat-rate taxpaying farmers and those taxed under the general rules.

\section{Conclusions and recommendations}

Understanding the essence of VAT taxation is a prerequisite for a proper approach to estimating costs and benefits resulting from the choice between the flat-rate form and the general rules of VAT taxation for agricultural activity.

Based on the conducted research it can be concluded that: 
1) The mathematical dependence developed in this paper allows farmers to determine additional costs incurred by the flat-rate taxpaying farmer. These costs result from the surplus of VAT paid at the purchase (which is the cost) over the flat-rate VAT obtained at the sale transaction (which is the income).The generals rules of taxation is a batter solution than flat-rate if this surplus occurs.

2) When making such a choice, one should consider additional costs related to taxation under general rules, i.e. keeping additional records, submitting relevant tax statements and collecting accounting documents. Within these costs, it would also be necessary to take into account solutions implemented in Poland to counter the tax gap and mainly related to VAT payers taxed under general taxation rules.

3) The topic that requires more detailed research is the practical application of legal solutions by farmers. It is worth noting that taxation under general rules is more favourable when a farmer purchases means of production. When agricultural products are sold, the flat-rate form of taxation is more profitable. This situation creates room for informal tax optimization by farmers operating together but under different forms of taxation.

\section{Bibliography:}

1. Brodzinska K. (2015), Podatek VAT w rolnictwie a proces modernizacji gospodarstw rolnych - studium przypadku,[VAT in agriculture and the process of modernization of agricultural holdings - case study], Roczniki Naukowe SERiA, XVII (3), Warszawa, Poznan, Krakow, pp. 56-61.

2. Dziemianowicz R. I. (2006), Podatek od wartosci dodanej a rynek rolny [Value added tax and agricultural market], Roczniki Naukowe SERiA VIII (2), Warszawa, Poznan, Krakow, pp. 30- 34.

3. Filipiak T. (2007), Podatek VAT w gospodarstwach rolnych [VAT in the farms], Roczniki Naukowe SERiA IX (1), Warszawa, Poznan, Krakow, pp. 109-114.

4. Gruziel K. (2009), Skutki zmian w rozliczaniu podatku VAT w gospodarstwach indywidualnych [Consequences of changes in VAT settlements for individual farms], Roczniki Naukowe SERiA XI(1), Warszawa, Poznan, Krakow, pp. 130-135.

5. Kondraszuk T. (2016), Wybrane problemy rozliczania VAT w rolnictwie [Selected problems of VAT accounting in agriculture], Roczniki Naukowe SERiA XVIII (2), Warszawa, Poznan, Krakow, s. 154-159.

6. Kondraszuk T., Jaworski J. (2017), W poszukiwaniu kryterium wyboru formy opodatkowania VAT w rolnictwie [In search of the criterion of choosing the form of VAT taxation in agriculture], Zeszyty Naukowe Uniwersytetu Szczecinskiego. Finanse, Rynki Finansowe, Ubezpieczenia, nr 1/2017 (85), pp. 47-58.

7. Pastuszka J (2016), Planowane rozwiazania ograniczajace luke podatkowa VAT w Polsce. Nowe metody wykrywania nieprawidlowosci i ich eliminacji [Planned solutions to limit the VAT tax gap in Poland. New methods of detecting irregularities and their elimination], Kontrola Panstwowa, 2016, nr 61(4), s. $102-119$.

8. Szelagowska A., Goraj L. (2000), Podatek od towarow i uslug (VAT) w rolnictwie, [Value added tax (VAT) in agriculture], Warszawa.

9. Tokarski A, Tokarski M.. Voss G. (2015), Ksiegowosc w malej i sredniej firmie. Uproszczone formy ewidencji, [Accounting in a small and medium company. Simplified forms of records], Warszawa, Wydawnictwo CeDeWu.

10. Tratkiewicz T. (2016), Luka w VAT - sposoby przeciwdzialania w Polsce i UE [VAT gap - ways to counteract in Poland and the EU], Studia Ekonomiczne. Zeszyty Naukowe Uniwersytetu Ekonomicznego w Katowicach, nr 294, pp. 185-196.

11. Turowska W. (2010), Ewidencja, rozliczenie i skutki rozrachunkow przedsiebiorstw rolniczych z tytulu podatku VAT, [The registering, accounting and effects of the score-settling of farming enterprises on account of the value added tax], Zeszyty Naukowe Szkoly Glownej Gospodarstwa Wiejskiego w Warszawie, Ekonomika i Organizacja Gospodarki Zywnosciowe Nr 82, Warszawa, Wydawnictwo SGGW, pp. 229-237.

12. Ustawa z dnia 8 stycznia 1993 r. o podatku od towarow i uslug oraz o podatku akcyzowym [Act of January 8,1993 on tax on goods and services and on excise duty] Dz. U Nr 11 poz. 50 z pozn. zm.

13. Ustawa z dnia 20 lipca 2000 r. o zmianie ustawy o podatku od towarow i uslug podatku akcyzowym i oplacie skarbowej [Act of 20 July 2000 amending the act on the tax on goods and services of excise duty and stamp duty]. Dz.U. Nr 68, poz. 805).

14. Ustawa z dnia 11 marca 2004 r. o podatku od towarow i uslug [Act of 11 March 2004 on tax on goods and services]. Dz.U. Nr 54, poz. 535 z pozn. zm.

15. Wegrzyn A., Metodyka ewidencji i rozliczania VAT w rolnictwie, [Methodology of VAT records and VAT accounting in agriculture], Roczniki Naukowe SERiA IX(1), Warszawa, Poznan, Krakow, s. 532-536, 2007. 
Proceedings of the 2018 International Conference "ECONOMIC SCIENCE FOR RURAL DEVELOPMENT" No 49

Jelgava, LLU ESAF, 911 May 2018, pp. 124-130 DOI $10.22616 / E S R D .2018 .127$

16. Zabielska D., Uwarunkowania zasad funkcjonowania podatku VAT w gospodarstwach rolnych, [Conditioning of the operation of the VAT rules in agricultural], Zeszyty Naukowe SGGW, Ekonomika i Organizacja Gospodarki Zywnosciowej, nr. 89, s. 61-73, 2011.

17. Czy-rolnikowi-oplaca-sie-byc-czynnym-podatnikiem-VAT.html,[Does the farmer pay to be an active VAT taxpayer]. Retrieved May 15, 2016, from http://ksiegowosc.infor.pl/podatki/podatki-na-wsi/142109

18. Ryczalt-czy-vat, [A flat-rate VAT system or general rules] Retrieved May 15, 2016 from www.podatki.egospodarka.pl/kalkulator/vat-w-rolnictwie. 